International Journal of English Literature and Social Sciences
Vol-7, Issue-1; Jan-Feb, 2022
Journal Home Page Available: https://ijels.com/
Journal DOI: $10.22161 /$ ijels

Peer-Reviewed Journal

\title{
Traumatic History and Transcultural Memory: A Reading of Numair Atif Choudhury's Babu Bangladesh in the context of Nation formation
}

\author{
Dr. Sagarika Dutta
}

Department of English, Hooghly Women's College, Burdwan University, West Bengal, India

Received: 16 Dec 2021; Received in revised form: 08 Feb 2022; Accepted: 16 Feb 2022; Available online: 24 Feb 2022

(C)2022 The Author(s). Published by Infogain Publication. This is an open access article under the CC BY license

(https://creativecommons.org/licenses/by/4.0/).

\begin{abstract}
In the age of interdisciplinary studies Literary and Memory Studies is an emerging field of interest to young scholars and researchers. The manner in which Memory Studies interlink across various disciplines as history, geography, literature, psychology is worthy of exploring. Cultural memory entails convergence of fields such as cultural history, social psychology, media archaeology, political philosophy, comparative literature and relate past to the present. It is bifocal in nature since it leads to both remembering and forgetting. There are diverse ways in which Memory studies can be located in literary and media studies. My focus is to highlight how an exploration of memory studies further leads to a study of psychological trauma buried deep in the memory of an individual as well as its culture. The experience of undergoing the two World Wars, Holocaust, 9/11 episode, 1971 Bangladesh Liberation War, political strife in Afghanistan are major areas that can be studied with the aid of memory studies. I shall highlight on this specific area of memory studies by contextualizing how memory operates by its twin process of remembering and forgetting to bring out the trauma of the civilians of East Pakistan who had witnessed the 1971 Bangladesh Liberation War. For this purpose Numair Atif Choudhary's Babu Bangladesh (2019) is chosen to elucidate how the process of nation building is intrinsically connected to the present and past lives of its citizens. The narrative of formation of a new nation is continually questioned and reframed by the oral narratives of the generations of people who have witnessed its creation.
\end{abstract}

Keywords - Fiction, history, memory, intergenerational trauma, transcultural memory.

Historical narratives that preside over archives, official histories and museums remind us of what has passed or, in other words, what is no longer present amongst us. However, they do not reveal an absolute truth. Instead they lead us to the process of constructing truths based on conflicting interests. However, memory operates as a selective process and often becomes a political weapon in case of the victims of war and genocide when forgetting has been deliberately emphasized by hegemonic forces of society. Maurice Halbwachs was the first sociologist to redeem the topic of memory for the field of social interaction. He rejected the idea that memory was the result of the impression of real events on the human mind. On the contrary he established the thesis that people weave their memories together on the basis of the various forms of interaction they engage in with other individuals. Nevertheless, it is, in fact, collective since the individual, even if alone, is the product of social interactions and views the world through collective constructs as language. Memory in this case performs an important function as it allows us a possibility of looking at the alternative narratives that have been buried so far in order to maintain social stability both by individuals and by hegemonic power structures of society.

The French philosopher Paul Ricoeur was able to contextualize memory, history and forgetting. In his view, memory is an ongoing task that is always able to superimpose itself on pre-established structural processes. 
Throughout the 20th century, the major demand of the victims of totalitarian and repressive governments found expression in movements to reclaim memory. Archives, artifacts and accounts of the past have been used as proof of a past that was deliberately forgotten in official versions of history. Memory is therefore associated with those who wield power, since they decide which narratives should be remembered, preserved and disseminated. However, the memory of those who are powerless is intentionally pushed to the margins so as to not allow any ruptures in the socially fabricated narratives disseminated so far by the powerful.

Numair Choudhury's imaginative novel, Babu Bangladesh! is an attempt to recover those memories that were intricately associated with the painful past of Bangladesh. The novel is a fictional documentation of the life of Babu Abdul Majumdar, known later in his life simply as Babu or Babu Bangladesh. It also offers a vivid biography of a young country, born and raised in violence, fraying under the assault of corrupt governments, foreign intelligence agencies, religious fundamentalists and ruthless oligarchs. Recounted from the year 2028, the novel is narrated by an author who is fascinated to find who is Babu exactly. The narrator tries to examine the personal collection of Babu's diaries and essays, handed to him by a fishmonger, whom Babu had entrusted his belongings once upon a time. Since we get a glimpse of Babu's life and other significant details regarding the nation from the personal memoirs of Babu, therefore, memory functions an important aspect here. Everything the narrator conveys us is filtered through the memory lens of Babu, who decides upon what the readers shall know. Araújo and Santos in "History, Memory and Forgetting" (2009) argue that memory is not only a "knowledge of the past, but also only of that portion of it which has been already experienced by the subject" (399). Babu's memoirs not only allow us a glimpse of his life but also the condition East Pakistan before the 1971 Liberation War and of newly formed Bangladesh after the war.

In an article "Babu Bangladesh: A Literary agent remembers the making of a debut novel- and its author's death", Kanishka Choudhury explained that Babu Bangladesh! was conceived during his $\mathrm{PhD}$ thesis at the University of Texas in Dallas and publishing the novel was a big step for Numair. "He was a perfectionist," Gupta recalled. "If he was alive, I'm sure he would still be working on the manuscript". Choudhury, from the vantage point of the future, perhaps turns to alternative narratives, indigenous superstitions and enchanted and inexplicable byroads to right these wrongs. The novel comprises chapters named the "BUILDING", "TREE', "SNAKE', "ISLAND" and "BIRD" consequently. Initially when the story begins, we the readers get a glimpse of Babu as someone who is reputed as a "spirited environmentalist" (5) advocating for development in poverty-stricken regions of newly formed nation, Bangladesh. Towards the end of the novel Babu goes missing in 2021 and the novel traces back the trajectory of how Babu became famous among the civilians of Bangladesh and what led to his sudden absence from the place he loved so deeply.

Intrigued by Babu's life and his passion for serving the common citizens, the narrator of the story embarks on the journey to capture the minute details of his life. The narrator defends his work saying, "My work for the past nine years has been to powder through rubble to retrieve fragments of what is Babu Bangladesh" (6). Through the novel Numair Asif Choudhury wanted to search for a "perfect gateway to the examination of obscure and alternative narratives pertaining to Bangladesh" (16) and Babu was somehow intricately connected to some "rare and institutionally unacknowledged accounts" (16). Babu is therefore a gateway to an understanding of innumerable unacknowledged narratives that lay buried under the grand narrative of nation formation. An examination of Babu's life allows us the possibility to understand other alternative narratives than found in officially sanctioned histories. Furthermore, as we go through Babu's problematic life, we come across larger issues as "deforestation, institutional corruption, food modification and human genomic violations to the eradication of sacred ecologies and ethnic narratives" that were matter of concern in post independent Bangladesh (18). The novelist explains his fascination with Babu's life saying that an examination of Babu's life allows "expounding on subaltern practices, in addition to permitting reflections on current world orders and disorders" (18).

The novel chronicles how Babu's birth year coincided with the birth of a new nation, i.e., Bangladesh. In the year 1971, East Pakistan got independence from West Pakistan and newly formed nation Bangladesh came into being. However, the novel successfully portrays the internal conflicts within East Pakistan much before the 1971 Liberation War and also traces various demonstrations of violence and strife post 1971 War in independent Bangladesh. It begins by describing the riots between the Bengali Hindus and Bengali Muslims in 1950 (40). Due to the riots, there were arson, loot, rape and murder of thousands of Hindus. Moreover, the proclamation of the Balfour Declaration almost three decades ago the War of independence resulted in "bloodshed" in the river port of Muladi in Barisal district (40). During this time, several of Hindus had sought shelter at the police station only to be killed within its 
precincts. In the village of Madhabpasha, three hundred Hindus were rounded up by a Muslim mob and made to "squat in a row" after which their heads have been serially chopped off (40). Babu's Hindu friend Jishnu recounted to him his memories of surviving such a time in Barisal. Jishnu's memories were later found in Babu's memoirs by the narrator and it recounted how Jishnu's father had been beaten up in broad daylight at the marketplace by young Muslim boys. The memoir also expressed Jishnu's trauma the day his uncle in Barisal had been killed because his uncle's Hindu neighbours were incensed on learning that they had been sheltering a Christian in their homes. In an online article "Muslim Riots of East Bengal in 1950", Arti Agarwal notes that 5.6 Million Hindus massacred, raped or forced to flee in the riots. The trauma of belonging and not belonging to a nation is brought through Jishnu's narrative that highlights the pain that the Bengali Hindus had undergone in Bangladesh during the riots in 1950. Although they belonged to East Pakistan and considered themselves citizens, the Muslim population believed they were outsiders and tortured the Hindus without any significant reason.

There is also a mention of Santali population residing in Bangladesh in the novel though the character of Kanu, Babu's caretaker. In 1980s the Santali population in Bangladesh was around "two hundred thousand" (45). These tribal people had to suffer at the "hands of invaders, non-tribal landlords, money lenders and colonial despots" (46). In the article, "The Santals of Bangladesh", Francesco Cavallaro and Tania Rahman argue that the number of Santal people living in Bangladesh is still debatable. In a survey conducted in 1941, the Santal population was recorded as 829,025 . In the censuses conducted after the Partition in 1947, the Santals were not distinguished from other minority groups. In 2001, according to one estimate, the Santal population in Bangladesh was numbered around 157,000 but the World Bank report (2008) has estimated the number around to be 300,000. Kanu spoke how his father, a Santal, assisted the Bengalis in their fight for independence yet he was not considered worthy of respect. Not only the Bengali Hindus but also the Santals were considered as outsider in East Pakistan by the Muslims. The unabated violence in independent Bangladesh is also portrayed in the section where Kanu has been attacked and murdered by the BNP (Bangladesh Nationalist Party) men, who had mistakenly assumed Kanu to be Hamza, a man of the Opposition party. There were several unnamed others as Kanu who had to face similar consequence in life for being a Santal or belonging to any other sect than Muslim.

Moreover, there were several independent parties that fought for attaining power position in post 1971
Bangladesh. Babu recounts in his memoir how the streets of Tangail were filled with troublemakers after Kanu was murdered. Babu saw how the policemen who came to investigate Kanu's murder were reluctant to find the truth. Moreover, they seemed not bothered by the fact that an innocent man had been killed. Babu was traumatized wondering how could there be no justice. Due to such unabated violence, Babu's father began staying indoors. This was a reason for Babu to be happy but he was traumatized wondering what made the officers not investigate Kanu's murder. As Kanu was very close to Babu, he felt tormented as if he had lost some near kin.

The framing of the Constitution in 1972 is another significant development mentioned in the novel. The Four Founding Principles in the first Bangladeshi Constitution included secularism alongside nationalism, socialism and democracy. However, there were protests to insert Islam into the legislative codes. Sheikh Mujib, the founder-president of the country, boasted that Bangladesh as the "second most populous 'Muslim state' in the world" (59). Mujib revived and then elevated the Islamic Academy as a foundation to propagate Islamic ideals. The government at that point of time also buckled to "religious pressure" and tripled the "annual budgetary allocation for Islamic schools in 1973" (59). Therefore, Bangladesh was not shaping itself as a secular nation that it had initially declared itself to be but preferred Islam as a model to be followed universally.

Moreover, General Gia increased the prominence of Islam in Bangladesh and the "founding principle of 'secularism' was removed from the Constitution" in 1977 (60). In June 1988, when General Ershad mandated Islam as the "Bangladeshi state religion", widespread discontentment was apparent among the Bengali speaking Muslims. Politicians, intellectuals and students rejected the governmental imposition. Even though the nation was 85 per cent Muslim at the time, protests broke out on many college campuses including the Dhaka University campus. People walked on the streets to protest. While the Supreme Court would restore secularism as one of the basic tenets of the Constitution in 2010, the decades of "religious conditioning" had undeniably changed the character of the nation (60). East Pakistan in the late 1960s comprised of 4 per cent Christian, 9 per cent Buddhist, 19 per cent Hindu and 68 per cent Muslim. An online article "Bangladeshis protest against ending Islam as State religion" published in New Indian Express mentions that more than 90 percent of Bangladesh's 160 million people are Muslim, Hindus and Buddhists. Military dictator H.M. Ershad declared Islam the state religion in 1988 to win support during a campaign by major political parties but had to resign amid large protests in 1990. Prime Minister Sheikh Hasina brought 
back secularism as a pillar of the constitution in 2011, but retained Islam as the state religion. Therefore, the people who were non-Muslims were relegated to the margins allowing further strife in the country which was already in trouble.

The internal disturbances slowly led to grievances among people of different religion than the Muslims. The Vested Property Act of 1974 legitimized the seizing of properties from Bangladeshi Hindus and encouraged their exodus, which had initially been spurred by Pakistan's mass exterminations. This exodus resulted in one of the largest displacements of a population based on "ethnic or religious identity" and nearly "ten million Bengali Hindus" fled from Bangladesh to India. Dhaka University in the mid-nineties displayed a series of agitations (83). The Bangladeshis wanted to tear down the dictatorship and set up a leftist government (83).

Students from the upper-middle and middle class backgrounds had become frantic to leave the motherland and resume their studies abroad. There was a common Bangladeshi hysteria to immigrate in the mid-nineties. The Dhaka University Central Students Union (DUCSU) that had concentrated on civil reformation had now become drug dens. The student politics in Bangladesh was infected with "violence and greed" (85). In a joint paper "Student Politics and Political Violence in Bangladesh" (2020), Kuttig, Suykens and Islam mention that the student politics plays a formidable role in Bangladeshi politics. Politically aligned students are inextricably connected to party politics, contributing significantly to political violence in the country and at the same time are often in training for future political positions, linking violence with politics in a self-reinforcing cycle.

Student political wings use strong incentives to encourage new students to join, and disincentives for nonparticipation. Incoming students are incentivized to join specific party wings through access to scarce on-campus accommodations and other student benefits which are denied to other students [. . .] Conversely, those who do not participate are often denied decent accommodations, access to on-campus resources, or protection from criminal activities of the dominating political student wing. (ix)

In 1994 the republic had an unofficial two-party system, with the Bangladeshi Nationalist Party (BNP) and the Awami League (AL) being the main contenders (85). The novelist summarizes the miserable state of Bangladesh at that point saying, it would be a place of "transnational and multi-level deep state anarchy" (85). Controllers and implementers included foreign intelligence and security apparatuses, transnational cartels, political and fiduciary heavyweights, oligarchs and dynasts, military and civil bureaucrats, and the clergy were the key players who competed for leverage. There was anarchy all round and both BNP and JP (Jatiya Party) stressed the importance of democracy, transparency, nationalism, free market economics. Another part, WP (Workers Party) evolved that sought to implement socialist reforms through democratic means. However, in spite of ideological differences, most of the Bangladeshi leaders of the above mentioned parties operated with interest for "personal advancement and selfenrichment" (86). There were also frequent partisian formations to secure "short-term goals" (86). "Bribery, forgery, kidnapping and murder were standard protocol, and student recruits were organized into hit squads when needed. The entire political situation of the country worsened and people fought among themselves to occupy power. In this situation the students who studied but got engaged in active politics suffered the most not knowing which party to join. The innocent civilians had to bear the consequence of these conflicts and even after the independence of the country in 1971, they found no peace. Due to the strife in political level their lives were at stake. They lived in a state of perpetual trauma and the novel offers us a glimpse of the state of the civilians who did not know what to do.

In 1994, Babu joined a much smaller party, the Jatiyo Samajtantrik Dal (JSD) that had sparked off in 1972 when socialist activists, military officers and student leaders consolidated their organizations. They fought for democratic redistribution of wealth and governmental decentralization (86-87). They were staunch proponents for the mobilization of female workers, for regulation of big business, and for prosecuting war criminals. The JSD party manifesto also vowed to reinstate democracy, socialism, secularism and nationalism as the Four Founding Principles as per the 1972 Constitution (87). These people retained the spirit of 1971 and the hope, idealism and desire to craft a golden motherland. In the economic and executive chaos that was seeping into the country, Babu was enthused by the example set by the JSD leaders. Though the Constitution forbade any elections before 1996, yet the Awami Leaguers wanted the BNP appointees to step down and have early elections. In this situation the violence escalated nationwide. The innocent Bangladeshi citizens begged the BNP and the opposition to reconcile their grievances but situations worsened and many felt that the "country was facing an impending civil war" (88). The assembly chamber in the Sangsad Bhaban 
would remain vacant as sessions were dissolved and "boycotts, protests and general strikes resumed" (89). According to the indexes prepared by Transparency International (TI), a Berlin-based organization, "Bangladesh was the world's most corrupt nation in 1992 and in 1993" (89). Babu and his friends could no longer sit back and witness the devastation of motherland and Babu joined the JSD in a more active role, as the national youth advisor. The New York Times mentions in an article "Study rates Bangladesh most Corrupt country" that according to the Transparency International, Bangladesh was rated as the most corrupt nation, with a score of 1.2. Nigeria, Paraguay, Madagascar, Angola, Kenya and Indonesia, in order, were the next most corrupt.

There is also a reference of the trauma faced by the sex workers of Tanbazar and Nimtoli who were uprooted forcibly by the police under the instruction of a political leader. Awami League representative, Mr Aman sought to eliminate the two red light areas from his jurisdiction. For three decades the business of prostitution spawned the area and there were many women who refused to return to their families in the hope of having a better future. These women had access to the top government officers both in police force and public administration offices. Therefore, when they were suddenly asked to vacate their shelters, they felt helpless. In 1999 Only 400 women were held captive in the raids of 1999. Rest of the women proved to be more powerful than the constables and fled. The captive women were soon released and were given rupees 5000 in cash, three egg laying hens and one sewing machine. Moreover, the women wanted to return to their occupation that they were engaged in. An article "Rights-Bangladesh" (1999), Tabibul Islam examines how the sex workers of Tanbazar and Nimtoli were forcibly arrested and evicted from their homes by the police. The United Nations Development Programme (UNDP) has chalked out a 2-million dollarprogramme for the rehabilitation of sex workers in four brothels, including Nimtoli and Tanbazar, $25 \mathrm{kms}$ from the Bangladesh capital city. The project titled, 'Capacity building for poverty alleviation and sustainable livelihood of socially under privileged women', seeked to give medical treatment and vocational training. It would be implemented through the government's Department of Social Welfare. Later in the novel, we the readers know that Babu's mother had also worked for the rehabilitation of many women who were rescued from the army camp post 1971 war. As a result Babu always held such women in high regard.

The novel also highlights the series of protests held in the Dhaka University campus before the 1971 War. Due to the imposition of Urdu as the official language of united Pakistan, the East Pakistanis felt neglected as they mainly spoke Bengali. On 21 February 1952 the Language Movement took place which gave prominence to Bengali than Urdu. Moreover, the devastating cyclone of November 1970 that hit the country left "three hundred thousand to one million Bengalis dead" and "millions without food and shelter" (142). These two episodes led to additional grievance among the East Pakistani civilians who found that West Pakistan was uninterested in their matters. There was no financial assistance from the West Pakistanis even after so much of loss. The East Pakistanis felt agitated and began demonstrations against the West Pakistani government. In order to curb the protest movements, on $25^{\text {th }}$ March, 1971 the West Pakistani army attacked the East Pakistanis. The novel recounts the happenings post $25^{\text {th }}$ March as:

By April, almost thirty million had walked to Indian borders. [. . . ] The mass exterminations of 1971 vie with the annihilation of the Soviet POWs, Chairman Mao's Cultural Revolution, the Jewish holocaust and the Rwandan genocide as the most concentrated act of civilian-murder. The Guinness Book of World Records lists the Bangladeshi genocide among the deadliest five of the twentieth century. (144)

India assisted the Bangladeshi freedom fighters to defeat the Pakistani forces. However, it is also said that the Bangladeshi factories were looted by the Indian forces and some of the agreements were also violated by India. The events of the 1971 war are so horrific that "no memorial service, no international conference, nor any number of commemorative statues, songs, books, paintings or movies have been able to undo what had been done" (145-146). Anam Zakaria in article 1971 India-Pakistan War: Memory as Peacemaker (2020) mentions that in official Pakistani memory, "1971 is selectively remembered". "There isn't a blanket denial of events. Instead, awkward pauses and silences mar the memory of the 24 years in which East and West Pakistan coexisted, with uncomfortable truths circumvented, if not distorted". Events of the nine-month long war is also "selectively mined and presented", creating a distinct national narrative on the birth of Bangladesh in the collective imagination of Pakistan.

The impact of fighting the 1971 War on such a large scale left its toll on the army that had gone to East Pakistan to fight. There were many officers who began questioning the feasibility of subduing the East Wing. The 'non-martial' Bengalis were proving themselves deadly in 
jungle and forest combat. The condition of the West Pakistani soldiers is explained as:

Many Pakistani soldiers demonstrated
symptoms of nyctophobia and
experienced incapacitating night terrors.
It was quietly admitted that their
servicemen had been checked in the
south by a contingent of female warriors
from aboriginal tribes. Even more
demoralizing for the foreign troops was
the realization that the hill-dwelling
women had stopped their jawans with
bows and arrows. (191)

There were rumors that Major Saud, along with two others, had been hospitalized in a psychiatric ward in Western Wing. Moreover, the soldiers who had embarked on the task of tree felling were full of "dejection and paranoia" (191). On $16^{\text {th }}$ December 1971, nine months after the commencement of the Operation Searchlight, Pakistani officials surrendered defeat to the Indian army. Though the army and its officers were deployed to fight War without emotions, the experience of fighting and killing had its effect on these men who felt lost towards the end of the War. They understood the futility of fighting and were traumatized by the experience of killing innocent civilians. They felt trapped in East Bengal and many of the men were admitted to hospitals after they returned home for psychiatric treatment.

After the Pakistani army surrendered, the Indian government compelled the government of Bangladesh to sign "uneven agreements that paved the way for decades of exploitation" (194). Pakistan, similarly, did not return the hundreds of millions of dollars it had hijacked from international donors, money that had been sent to help the Bangladeshi victims of 1970 cyclone. "The government of Pakistan has never apologized for or even acknowledged its actions in 1971. This denial continues to offend Bangladeshis" (194). The leaders in Islamabad refused to repatriate their own stranded 'Biharis' from Bangladesh, leaving them suspended for decades. After the war, the treacheries that followed were innumerous. Duplicity abounded within the Bengali files too. Testimonials followed that flooded with "torture and systematic murder" that the Bangladeshi collaborators had helped the enemy perpetrate. While the Biharis attested how they too had been slaughtered and abused by the Bengali freedom fighters; the Bangladeshi women pointed fingers at their own Mukti Bahini.

The problems concerning the Bihari community is one of the oldest long-standing issues between Bangladesh and Pakistan. They were never accepted as citizens in the Bangladeshi society even after spending generations. Md Kamrul Hasan Arif in the article "Status of the Bihari Community in Bangladesh under Domestic and International Law" (2018) mentions that in 1971, after the independence of Bangladesh, the Bihari lost their citizenship. They were stateless and living in various camps in different parts of Bangladesh. The community wanted to be repatriated to their own country, Pakistan. They were denied Pakistani citizenship status, although a large number have been repatriated to Pakistan as their country of origin. In March 2015 the Supreme Court of Pakistan rejected the issue of stranded Pakistanis in Bangladesh regarding repatriation or taking these people back. The Bihari population of Bangladesh has been left stranded in between and they do not know which country to belong.

Moreover, with the breakdown of law and order during the War, the armed men of East Pakistan raped their own women. Reports described the targets as mainly Hindu women, but Bengali women, irrespective of religion, caste, or class, came under attack by the West Pakistani military backed by local collaborators, who were fighting guerrilla forces called the Mukti Bahini. Kajalie Shehreen Islam in "Breaking Down the Birangona" comments, "Women and girls from the ages of seven to seventy-five were raped, gang-raped, and either killed or taken away" by the military to become sex slaves to officers and soldiers for the duration of the war. Even as the Pakistani forces surrendered in December 1971, some reportedly claimed to be "leaving their 'seed' behind in the women they had impregnated in the mass rape" (2133). Moreover, over the next few years, freedom fighters found themselves marginalized by the Bangladeshi government that was vulnerable to "cronyism, and many war stories . . ." (195). There was utter confusion all around and Sheikh Mujib was assassinated in 1975 and some of his conspirators became national leaders. In Pakistan, similarly, there was anarchy all around. Prime Minster Bhutto was hanged in 1979 and General Yahya Khan was overthrown. General Niazi became a "scapegoat" for signing the capitulation (195). The major and other rank holders attempted to publish apologies for the atrocities they committed.

Another significant area that remained acknowledged was the rape of nearly "2,00,000 and $4,00,000$ Bengali women over a period of nine months. The condition of these women was worse and they were not accepted back in their families or society. Many of them became mad or committed suicide. Though they have been elevated to the statues of war heroines after the war but the loss of honour that they faced could never be compensated. Around 25,000 women turned pregnant as a 
result of the forced rape during and after the 1971 War.Soldiers demanded incentives from the government for taking these women as wives; these men requested gifts ranging from the latest model of Japanese motorbikes to housing materials, from new refrigerators to the publication of unpublished poems (198). In an online article "Bangladesh War Heroines Honored at Last" (2019), Stephan Uttom and Rock Ronald note how the military also raped and made "sex slaves of 200,000 to 300,000 women". It is believed that the "rape spree was a premeditated tool to terrorize and break up families of independence supporters as rape is considered a loss of honor and a cause of social ostracism in conservative Bangladeshi society". Although the country gained independence, the trauma and humiliation these raped women faced throughout their lives can never be estimated. They were considered as a shame upon their families and society and in no way were they integrated back in lives. In order to atone their suffering they were called Birangonas or war heroines by the government of Bangladesh after the War. However, the memories of the War and the experience of being ravished by the army men never left them.

The novel also chronicles how Babu left Dhaka in 1999 following the Sangsad Bhaban bombing debacle and how he immigrated to Dubai to work. The later development in the novel recounts how he returned to see the country in mid-2001. A sweeping reference is also made about the Bangladeshi Hindus in the novel and their condition post 1971 war. After 1971 war, whenever there was any discontent in the country, the "Hindus were commonly delegated as scapegoats and executed" (213). The condition of the Bangladeshi Hindus is described as:

Over the decades of persecution, millions of Hindus sought refuge in India. Those with deeper pockets and better luck left for Europe, Australia, Canada, the USA and Middle East, weeping as they departed. [. . .]. Former friends, neighbours, and lovers too, wept. They wept that brothers and sisters were being evicted in this most unBengali of ways, and they wept at their own negligence and fear .... (213)

The newly formed nation was under a lot of development projects and hence, forests were cut down regularly. By 2001, the forests of Madhupur and Tangail were done away with, for clearing grounds to be used as air force firing range, training centers and infrastructural enhancements. Bureaucrats turned a blind eye and filled their pockets as the medicinal plants were destroyed. There was influx of new settlers who found work at the saw mills, brick kilns, furniture shops, pesticide and hormone factories. Other newcomers got employment in pottery productions and as tailors. Babu was deeply affected by the deforestation and wanted to save the forests. Due to this effort, Babu got marked as someone who resisted development in the country. However, Babu won the favour of the Manasa-revering matriarchs of Tangail and Madhupur. Babu's call to the downtrodden and the underpriviledged would "infuriate brigadiers, captains, politicians and entrepreneurial highfliers" (228). Though the public eye was so fixed at him, very little could be done to silence him. He had the support of the masses. He wanted to build an ecological park that would be a merging ground of the biodiversity of Bangladesh. Babu also met the Jumma matriarchs and vowed them to remove the army from their 'tribal' lands (235). He argued how an eco-park who lead to employment for a number of Bengalis. Mohammad Shamsuddoha and Jasnuba Nasir in "Eco Tourism" (2011) argue how the first eco-park in Bangladesh, along with a botanical garden, was established in 2001. It was a development project on 1,996 acres of Chandranath Hills. The eco-park was established to facilitate biodiversity conservation, natural regeneration, new plantations and infrastructure development, as well as promoting nature-based tourism to generate income

On 29April, the Madhupur National Park was proclaimed as protected area by the United Nations Environment Programme and World Conservation Monitoring Centre. Babu was entrusted the role to see that building of bridges, roads, telecom cables, research laboratories and hotels reach completion. Bengalis and Jummas moved from temporary camps to single-storeyed homes with running water and electric facility. Various kinds of developments began surrounding the eco-park. With this Babu became a sensation and left his Kalabari home to live in his rudimentary lifestyle once again. He won his Madhupur seat again in 2007 and was appointed Advisor of Environment and Forest. Babu's enemies escalated in numbers and there were several who wished "Babu deceased" (281). However, there were a large number of people could viewed him as a barrier. Babu's murder plan was done by a CIA agent, Manzoor Iqbal but had to be later dropped as his daughter, Minnie, fell in love with Babu. Later there were accusations against Babu that he had led to theft of "355 million takas" from the Bangladeshi ministry of culture in 2021 (379). After this incident, Babu has not been seen in public places anymore. 


\section{CONCLUSION}

Towards the end of the novel, Numair Asif Choudhury puts certain unpredictabilities lying at the heart of Babu's life. Choudhury explains that " $[\mathrm{t}] \mathrm{o}$ measure the past, even if it does not wholly belong to us, is a tedious thing. We inevitably find ourselves thrashing about it in the belly of intimate moments we thought long since disappeared" (400). The novel highlights the trauma of the civilians of East Pakistan before the 1971 War and also reveals how the suffering did not come to an end after the independence. It is the common citizens who have to pay for the happenings at the national level. The personal and the political is so deeply connected that one cannot hide from its effects. The recuperative function of memory is also explored in the novel. We the readers gain knowledge of everything through Babu's personal memoirs that offer us an understanding of the pain and trauma of the people of Bangladesh. Therefore, memory allows us to read beyond historical events and allows a humanistic reading that is not possible otherwise.

\section{REFERENCES}

[1] Agarwal, Arti. "Ruthless Massacre of Hindus in 1971 War of East Pakistan-2.5 M Slaughtered". HinduGenocide. 24 Feb 2019. Web.

[2] Araujo, M.P.N and dos Santos, M.A. History, Memory and Forgetting: Political Implications. Trans. Sheena Caldwell. RCCS Annual Review. 1 (2009). Print.

[3] Arif, Md Kamrul Hasan. "Status of Bihari Community in Bangladesh under Domestic and International Law". Brill: International Journal on Minority and Group Rights. 25(4). 664-678. Print.

[4] "Bangladeshis Protest against ending Islam as State Religion". New Indian Express. 25 March 2016. Web.

[5] Cavallero, Francesco and Tania Rahman. "Santals of Bangladesh”. Linguistic Journal. Sep 2009. 192-220. Web.

[6] Gupta, Kanishka. ““'Babu Bangladesh: A Literary agent remembers the making of a debut novel- and its author's death". Scroll. 9 Nov 2019. Web.

[7] Islam, Tabibul. "Rights Bangladesh: New attempt to stop Women from being Sex Workers". Inter Press Service. 20 July 1999. Web.

[8] Kuttig, Julian, Bert Suykens and Aynul Islam. "Student Politics and Political Violence in Bangladesh". Ghent: Conflict Research Group and Micro governance Research Initiative, 2020. 1-117. Print.

[9] "Shamsuddoha, Mohammad and Jasnuba Nasir. "Eco Tourism: Descriptive Study on Sitakunda Eco Park in Chittagong Division of Bangladesh". International Journal of Educational Research and Technology. 2.1. June 2011. 813. Print.

[10] Shehreen, Kajalie. "Breaking down the Birangonas". International Journal of Communication 6(2012). 21312148. Print.
[11] Study rates Bangladesh most corrupt country". New York Times. 29 Aug 2002. Web.

[12] Uttom, Stephan and Rock Ronald Rosario. "Bangladesh's War heroines honored at Last". UCA News. 24 June 2019. Web.

[13] Zakaria, Anam. "1971 India-Pakistan War: Memory as Peacemaker". Open Es 